\title{
Stock dynamics of the brushtooth lizardfish Saurida undosquamis (Richardson, 1848) from a tropical multispecies fishery in the southeastern Arabian Sea
}

\author{
Theparambil Mohamed Najmudeen*, Pallangattu Kochukandan Seetha and Payiyappanal Ulahannan \\ Zacharia
}

Demersal Fisheries Division, ICAR-Central Marine Fisheries Research Institute, Ernakulam North PO, Kochi 682018, India

Received 2 November 2018 / Accepted 23 February 2019

Handling Editor: Nicole Richoux

\begin{abstract}
The brushtooth lizardfish Saurida undosquamis (Richardson, 1848) is a high trophic level benthic predator and is one among the most exploited demersal finfish species from eastern Arabian Sea by Indian trawlers. However, in recent years, the landings of many top predator fishes including S. undosquamis showed a declining trend resulting in a steady decline in the mean trophic levels of the fishes caught commercially in the region. We investigated the growth, mortality and stock dynamics of S. undosquamis harvested by mechanised trawls in the southeastern Arabian Sea, using length-based methods for the data collected during 2012-2016. Besides, Bayesian state-space implementation of the Schaefer model (BSM) and catch-based MSY (CMSY) estimation were also made using the data for the period 1985-2016. Total length of the fish ranged from 5.5 to $34.5 \mathrm{~cm}$ with average annual mean length of $22.0 \mathrm{~cm}$ during 2012-2016. The growth parameters $L_{\infty}$ and $K$ were $37.3 \mathrm{~cm}$ and 0.41 year $^{-1}$, respectively. The natural, fishing and total mortality coefficients were $0.92,2.58$ and 3.5 , respectively and exploitation ratio was 0.82 . The length at first maturity was estimated at $21.4 \mathrm{~cm}$ for females. The mean size in the catch is lower than the optimum length for exploitation. Fisheries reference points (MSY, $\left.\mathrm{F}_{\mathrm{msy}}, \mathrm{B}_{\mathrm{msy}}\right)$ as well as relative stock size $\left(\mathrm{B} / \mathrm{B}_{\mathrm{msy}}\right)$ and exploitation $\left(\mathrm{F} / \mathrm{F}_{\mathrm{msy}}\right)$ estimated from catch data and broad priors for resilience $(r)$, implies an exploitation of $30 \%$ below $\mathrm{B}_{\mathrm{msy}}$ level. Results from the length-based Thompson and Bell prediction model indicates that reducing the present level of fishing effort by $40 \%$ would lead to a harvest of the species at a sustainable level. As "fishing down food web" is reported in recent years from eastern Arabian Sea, the exploitation of top predators need to be maintained at sustainable levels to prevent ecosystem changes along the region.
\end{abstract}

Keywords: Bayesian Schaefer Model / exploitation / trophic level / lizardfish / population dynamics / southeastern Arabian Sea

\section{Introduction}

The tropical marine fishery in the southeastern Arabian Sea, bordered by coastal districts of the southwest coast of India, is characterised by the harvest of multi-species assemblages of finfish and shellfish groups employing multiple craft-gear combinations, with a dominance of mechanised multiday trawlnet operations (Vivekanandan et al., 2003). There is a notable shift in the target resources of trawlers in recent years from high value groups such as penaeid prawns to relatively low valued demersal finfish resources

\footnotetext{
*Corresponding author: najmudeentm@yahoo.com
}

(Vivekanandan et al., 2005; Najmudeen et al., 2014). Among the four coastal zones of seas around India, viz., southeastern and northeastern Arabian Sea, southern and northern Bay of Bengal, the southeastern Arabian Sea in the west coast of India is one of the most productive regions in the world oceans due to several physical and chemical processes (Prasanna Kumar et al., 2002). The zonation is made based on the ecological assemblages appear in the commercial fish landings in each zone (Vivekanandan et al., 2005). The difference in trends of the fishery between the coastal zones is due to the innate differences in the productivity between the coastal zones.

Lizardfishes, belonging to the family Scopielidae, are one of the prospective demersal fishery resources of the southeastern Arabian Sea, harvested mainly by trawl nets 
throughout the year with the peak fishery during AugustSeptember. Vivekanandan et al. (2009) reported a mean trophic level of 4.30 for lizardfishes and grouped them as top predators. The average annual catch of lizardfishes from the region amounts to 33300 tonnes which forms $40 \%$ of the total lizardfish landings of the southwest coast of India. Saurida undosquamis, commonly known as the brushtooth lizardfish, distributed all along the Indian coastal waters and forms a major demersal fishery in all maritime regions of India except the northern Bay of Bengal. Nearly $45 \%$ of the lizardfish landings of eastern Arabian Sea comprised of S. undosquamis, which are landed either as juveniles or adults and fetches reasonable price in the local market. Though some aspects of the biology of this species have been studied and reported from the southeastern Arabian Sea (Sivakami, 1999; Nansimole et al., 2014), knowledge on the stock dynamics and recruitment pattern of $S$. undosquamis is scarce except that of the limited reports available from other tropical maritime regions (Ingles and Pauly, 1984; Rajkumar et al., 2003; Cicek and Avsar, 2011; Metar et al., 2011; Wang et al., 2012; Mahmoud et al., 2014).

One of the basic requirements for scientific fisheries management is availability of consistent and adequate data on the stock size of the resources and their dynamics. The lengthbased models for fish stock assessment existing today are basically those designed for the temperate stocks, nevertheless, these are invariably applied in tropical fish stock assessments as well (Vivekanandan, 2005). Froese et al. (2017) presented Bayesian state-space implementation of the Schaefer model (BSM) and catch-based MSY (CMSY) analysis for the estimation of relative stock size and exploitation in data poor situations, which is suggested to be a possible alternative for the assessment of tropical Indian fish stocks where adequate data is not available to apply micro-analytical models of stock assessment. However, proper validation is essential prior to attempting CMSY analysis for Indian stocks. Vivekanandan et al. (2005) noted that the southeastern Arabian Sea remains as a distinct entity with the lowest mean trophic value (3.14), compared to the other three regions of seas around the coast of India. The fishing down to food web resulted in ecosystem changes owing to intensive fishing pressure along the region, which led to the depletion of catches of many top predator species during the last decade, including $S$. undosquamis. As there was no published report on the stock status and fishery dynamics of the top predator species $S$. undosquamis in the southeastern Arabian Sea, the present study aimed to provide an insight into the growth and stock dynamics of $S$. undosquamis caught by trawlers. The study also aimed at exploring the suitability of the use of Bayesian Schaefer model and catch-based CMSY method in estimating relative stock size and exploitation of tropical Indian stocks by comparing the results of the stock assessment of $S$. undosquamis using length-based methods.

\section{Materials and methods}

\subsection{Data sources}

The catch in tonnes and the fishing effort data in hours of trawling for the harvest of Saurida undosquamis by mechanised trawlers operating in the southeastern Arabian Sea were collected from major fish landing centres along the state of Kerala bordering southeastern Arabian Sea for a period of five years from 2012-2016 following the stratified multistage random sampling design (Srinath et al., 2005). For applying micro analytical models for stock assessment, 5012 numbers of $S$. undosquamis in the size range of 55 to $345 \mathrm{~mm}$ in total length were collected during 2012-2016 by weekly random sampling from the fish landing centres and the total length in centimetres $(\mathrm{cm})$ were measured to the nearest $0.01 \mathrm{~cm}$ and the weight $(\mathrm{g})$ recorded for each individual specimen.

\subsection{Growth models}

The von Bertalanffy growth parameters viz., asymptotic length $\left(L_{\infty}\right)$, growth co-efficient $(K)$ and age at zero length $t_{0}$, which are the most important inputs for modelling tropical fish stock dynamics, were estimated using the monthly data on length measurements of $S$. undosquamis. The total length $(\mathrm{cm})$ were pooled and grouped into $1 \mathrm{~cm}$ class interval, and analysed using the ELEFAN I module of FiSAT software (Gayanilo et al., 1996). The length-based growth performance index $(\varnothing)$ was calculated from the final estimates of $L_{\infty}$ and $K$ (Pauly and Munro, 1984). Length corresponding to the first value in the descending limb of the length converted catch curve was taken as the length at first capture $\left(L_{c}\right)$. The age at zero length $\left(t_{0}\right)$ was calculated from Pauly's (1979) empirical equation,

$\log \left(-t_{0}\right)=-0.392-0.275 \log L_{\infty}-1.038 \mathrm{~K}$.

The growth and age were estimated using the von Bertalanffy growth equation,

$$
L_{t}=L_{\infty}\left(1-\mathrm{e}^{-k\left(t-t_{0}\right)}\right) .
$$

Natural mortality (M) was estimated using Pauly's empirical formula (Pauly, 1980), using $27^{\circ} \mathrm{C}$ as the mean sea temperature. Total mortality $(\mathrm{Z})$ and exploitation rate $(\mathrm{E})$ were estimated from the length converted catch curve using FiSAT Software and exploitation rate (U) from the relation $\mathrm{U}=\mathrm{F} / \mathrm{Z} \times\left(1-\mathrm{e}^{-\mathrm{Z}}\right)$; where, $\mathrm{F}$ is the fishing mortality (Pauly, 1983a), which was estimated by $F=Z-M$. The exploitation ratio (E) was estimated using the equation $E=F / Z$. The longevity $t_{\max }$ was estimated from the equation of Pauly (1983b). Total stock (P) and biomass (B) were estimated from the ratios $\mathrm{Y} / \mathrm{U}$ and $\mathrm{Y} / \mathrm{F}$, respectively; where $\mathrm{Y}$ is the annual average yield in tonnes. Maximum sustainable yield (MSY) was calculated by the equation (Gulland, 1979) for exploited fish stocks, $\mathrm{MSY}=\mathrm{Z} \times 0.5 \times \mathrm{B}$.

The size at first maturity $\left(L_{\mathrm{m}}\right)$, which is the size at which $50 \%$ of the population attains sexual maturity was determined from 750 female specimens by fitting sigmoid curves to the proportion mature by length applying logistic regression model using the software WinBUGS, for Byesian analysis using Markov Chain Monte Carlo (MCMC) (Sathianandan and Mohamed, 2014).

\subsection{Stock dynamics and MSY estimates}

The relative yield per recruit $(\mathrm{Y} / \mathrm{R})$ and biomass per recruit $(B / R)$ at different levels of $F$ were estimated using LFSA package (Sparre, 1987) from Beverton and Holt yield per recruit model. The yield and biomass at different multiples of 


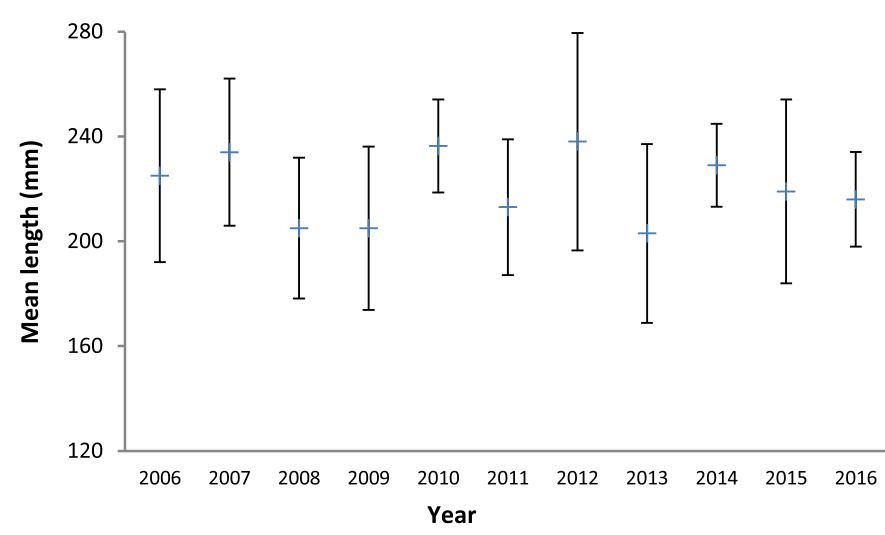

Fig. 1. Average annual mean length (mean $\pm \mathrm{SD}$ ) of $S$. undosquamis harvested by trawl nets along the southeastern Arabian Sea during 2006-2016.

F, MSY were also estimated using the Thompson Bell yield prediction models. Monthly and annual recruitment numbers and spawning stock biomass were estimated using lengthbased virtual population analysis (VPA).

Catch-MSY (CMSY) analysis and Bayesian state-space implementation of Schaefer model (BSM) (Froese et al., 2017) was applied to estimate fisheries reference points (MSY, $\mathrm{F}_{\mathrm{msy}}$, $\left.\mathrm{B}_{\mathrm{msy}}\right)$ as well as relative stock size $\left(\mathrm{B} / \mathrm{B}_{\mathrm{msy}}\right)$ and exploitation $\left(\mathrm{F} / \mathrm{F}_{\mathrm{msy}}\right)$, using catch and effort data of $S$. undosquamis harvested by trawlers for the period 1985-2016 from southeastern Arabian Sea. For this, catch and effort data were collected following the Stratified Multistage Random Sampling method (Srinath et al., 2005) to estimate the marine fish landings and available at the National Marine Fisheries Data Centre of CMFRI. CMSY/BSM analysis was run in R software module with a resilience value corresponding to "moderate resilience" adapted from FishBase (Froese and Pauly, 2018).

\section{Results}

The average annual harvest of Saurida undosquamis from the southeastern Arabian Sea during 2006-2016 was 5305 tonnes, which formed $43.8 \%$ of total lizardfish catches of the region. Fishery observed throughout the year and the most productive season was August-September period. The size range in the samples collected from trawl catches during 20122016 was $5.5-34.5 \mathrm{~cm}$. The annual mean length of $S$. undosquamis in the fishery ranged from $20.3 \mathrm{~cm}$ in 2013 to $23.8 \mathrm{~cm}$ in 2012 (Fig. 1), with an average annual mean length of $22.0 \mathrm{~cm}$ in the catch by trawls. Monthly average mean length in the fishery ranged from 18.4 to $25.4 \mathrm{~cm}$ with the highest mean length recorded in August, immediately after ending the seasonal closure for mechanised fishing in the region. The length at first maturity, at which $50 \%$ of the animals are mature, was estimated at $21.4 \mathrm{~cm}$ for females (Fig. 2). However, gonadal development and sexual maturity in the individuals of the species was observed to commence from $15 \mathrm{~cm}$ onwards.

\subsection{Population characteristics}

The growth parameters $L_{\infty}$ and $K$ were $37.3 \mathrm{~cm}$ and 0.41 year $^{-1}$, respectively (Fig. 3 ) and the length attained at the end of 1,2,3,4 and 5 year/s were $12.5,20.9,26.4,3.1$ and $32.5 \mathrm{~cm}$, respectively (Fig. 4). The growth performance index $\left(\mathscr{O}^{\prime}\right)$ was 2.92 and the longevity was 7.3 years. The asymptotic weight $\left(W_{\infty}\right)$ estimated was $376 \mathrm{~g}$ and the length at first capture of the species $\left(L_{\mathrm{c}}\right)$ was $14.9 \mathrm{~cm}$ at an age $\left(t_{\mathrm{c}}\right)$ of 1.25 years.

The average instantaneous rate of natural mortality, fishing mortality and total mortality were $0.92,2.88$ and 3.5, respectively (Fig. 5). The exploitation rate (U) of $S$. undosquamis in southeastern Arabian Sea was 0.85 and exploitation ratio (E) was 0.82 . The length at recruitment $\left(L_{\mathrm{r}}\right)$ was $8.5 \mathrm{~cm}$ at an age $\left(t_{\mathrm{r}}\right)$ of 0.63 years. The optimum size for exploitation $\left(L_{\mathrm{opt}}\right)$ is at $22.5 \mathrm{~cm}$ at the age $\left(t_{\mathrm{opt}}\right)$ of 2.3 years.

\subsection{Estimation of stock, MSY and Yield-per-recruit using length-based models}

The yield and biomass curves using Thompson and Bell prediction model showed that the maximum biomass and yield/recruit could be obtained at an $F$ factor of 0.6 from the present fishing effort (Fig. 6). The yield-per-recruit of $S$. undosquamis increases rapidly with the increase in fishing mortality reaching a maximum value of $35.52 \mathrm{~g}$ at its optimum effort, after which the yield-per-recruit was more or less stable with further increase in fishing mortality. The maximum sustainable yield and yield per recruit obtained by reducing the present fishing effort is $5738 \mathrm{t}$ and $35.52 \mathrm{~g}$, whereas at the present level of fishing, it is $5342 \mathrm{t}$ and $32.27 \mathrm{~g}$, respectively. The effect on different rates of exploitation and $L_{\mathrm{c}}$ values on the yield per recruit is explored and presented as a contour map (Fig. 7). To get optimum yield and biomass per recruit, the present fishing effort has to be reduced by $40 \%$. The increase in relative yield at the reduced effort would be $7.41 \%$.

The MSY estimated using Thompson and Bell prediction model was $5738 \mathrm{t}$. The annual spawning stock biomass of $S$. undosquamis estimated using length-based virtual population analysis (VPA) was $3017 \mathrm{t}$, which is $55 \%$ of the standing stock biomass. The annual recruitment number estimated was 171.3 million year ${ }^{-1}$. Monthly recruitment pattern indicates that the peak months of recruitment are May and August with the lowest numbers observed in December.

\subsection{Estimation of MSY, B/B $B_{\text {msy }}$ and $F / F_{\text {msy }}$ using CMSY/BSM analysis}

The medium resilience range from 0.2 to 0.8 in the current analysis is found reasonable because fewer viable $r-k$ combinations are found at the upper end of the $r$ range. There is a good overlap of the best $r-k$ estimate from CMSY using only catch and resilience and from BSM analysis using catch and CPUE data (Fig. 8). The catch relative to MSY and relative to stock size from CMSY and BSM overlap and cluster around the equilibrium curve, providing confidence in the assessment (Fig. 9). The MSY estimated using CMSY/BSM analysis was $4950 \mathrm{t}$ with a lower confidence limit $(95 \%)$ of $4510 \mathrm{t}$ and upper confidence limit of $5440 \mathrm{t}$ (Tab. 1). The biomass estimates indicate that the $\mathrm{B} / \mathrm{B}_{\text {msy }}$ stood a level $>1$ during 1986-1993 then substantially reduced to a level below 0.5 in 2007 (Fig. 10). However, there was a gradual increase in the values from 2008 onwards and the $\mathrm{B} / \mathrm{B}_{\mathrm{msy}}$ in the last year of analysis was 0.705 . The $\mathrm{B} / \mathrm{B}_{\text {msy }}$ was 1.78 with a confidence 


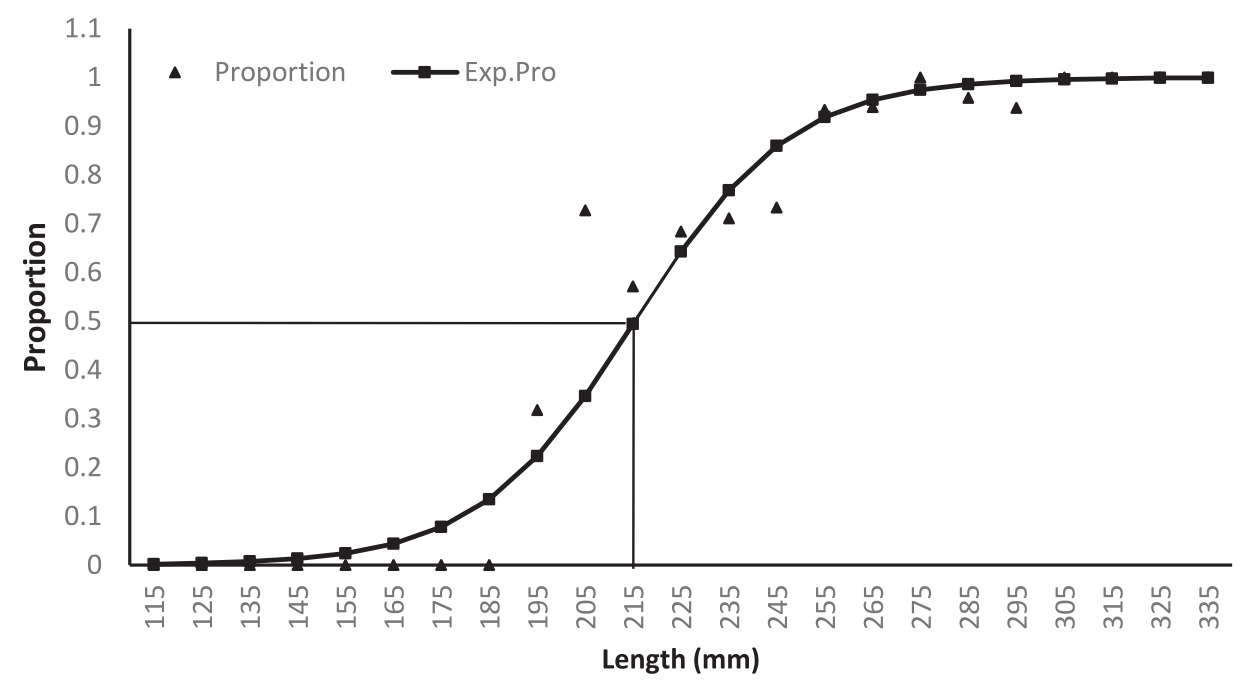

Fig. 2. Size at first maturity $\left(L_{\mathrm{m}}\right)$ among females of $S$. undosquamis from southeastern Arabian Sea.

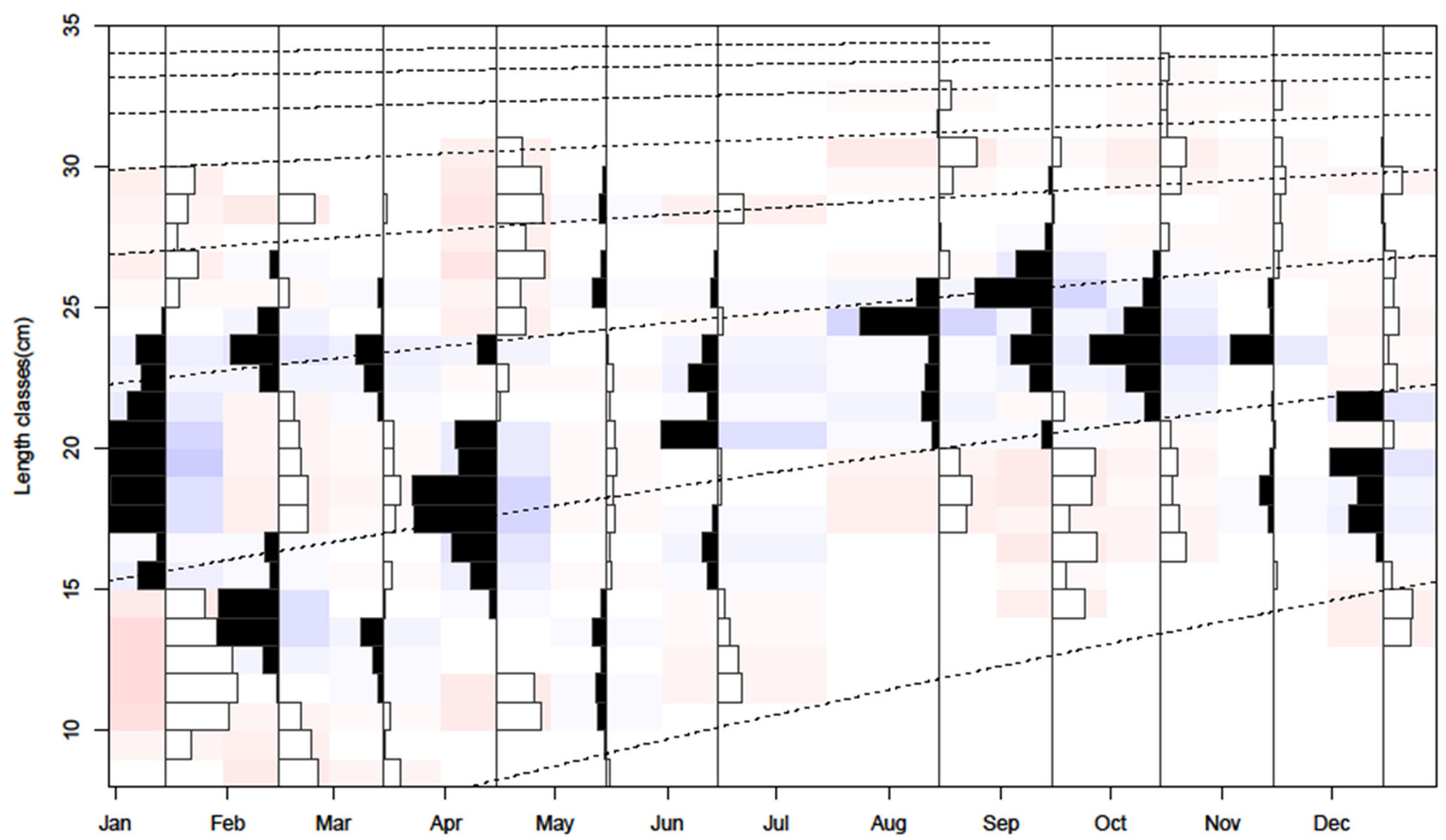

Fig. 3. von Bertalanffy growth curves estimated using restructured length-frequency data for $S$. undosquamis from southeastern Arabian Sea by ELEFAN I during 2012-2016.

limit of 1.26 to 2.62. The management-based BSM analysis indicates that the stock of $S$. undosquamis is either fully exploited or over-exploited in the southeastern Arabian Sea (Fig. 11).

\section{Discussion}

\subsection{Growth parameters}

Arabian Sea large marine ecosystem is considered as one among the highly productive ecosystems, in which the reported fish catch have remained relatively constant or shown increase over the past few decades (Desai and Bhargava, 1998; FAO, 2003). Lizardfishes form a potential demersal fishery in the southeastern Arabian Sea, for which good trawling grounds located north off Cochin along southwest coast of India (Bal and Rao, 1984). The expansion in vertical and horizontal fishing grounds of trawlers targeting demersal finfishes necessitates the appraisal of stock status of this important demersal finfish resource in the region. In the present study, age, growth and mortality parameters of $S$. undosquamis were estimated by employing length-based methods using the data 


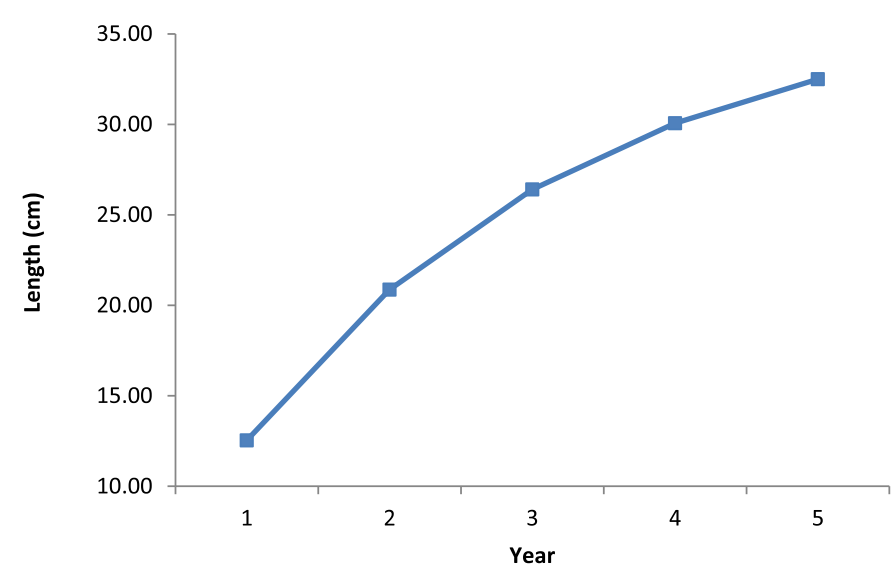

Fig. 4. Growth of $S$. undosquamis from southeastern Arabian Sea during different years.

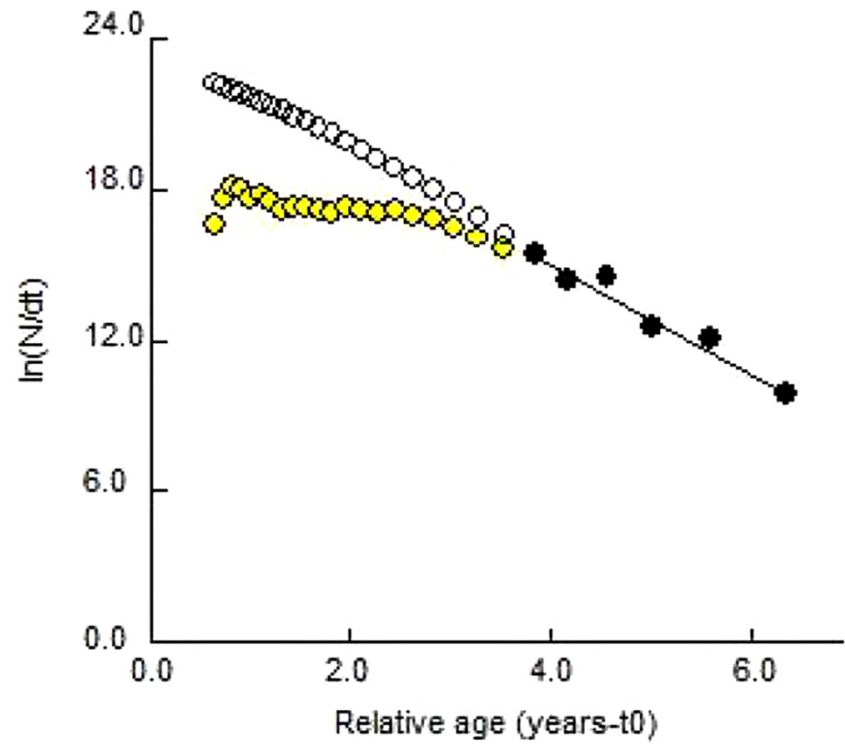

Fig. 5. Length converted catch curve for the estimation of mortality of S. undosquamis from southeastern Arabian Sea.

collected from commercial fisheries of the region. There are expected variations/differences in these parameters estimated using different methods and reported elsewhere. Most studies on growth and mortality parameters of $S$. undosquamis from different parts of the tropical oceans are based on the length frequency analyses (Chakraborty et al., 1997; Gokce et al., 2007; Wang et al., 2012; Mali et al., 2017). However, there are ample reports on age and growth determination based on the analysis of hard parts especially using otoliths (El Ganainy, 1992; Tureli and Erdem, 1997; Yoneda et al., 2002; Manasirli et al., 2011). The growth coefficient $k$ for $S$. undosquamis determined by length-based methods ranged from 0.26 to 1.20 year $^{-1}$, on the other hand, the growth rate estimates using hard parts were lower compared to that obtained using length frequency data and ranged from 0.11 to 0.59 year $^{-1}$.

Previous findings on the growth rates of $S$. undosquamis along the coastal waters of India indicated that the specimens from the west coast, bordering northeastern Arabian Sea grow

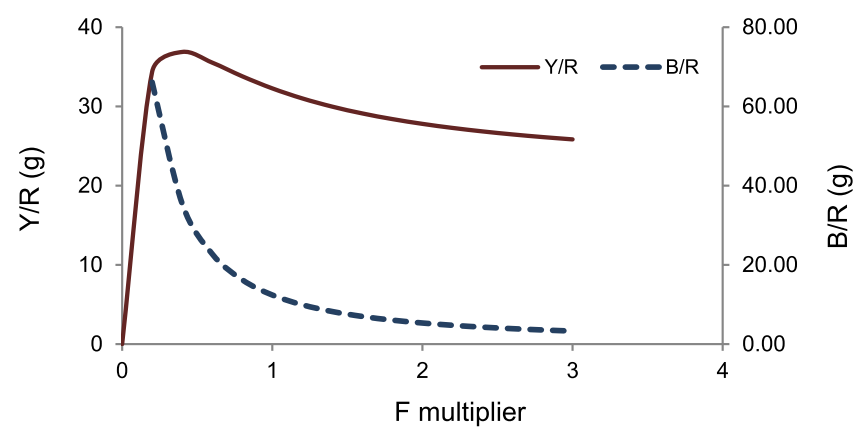

Fig. 6. Yield per recruit and biomass per recruit for $S$. undosquamis at different multiples of fishing mortality (F) using Thompson and Bell Prediction model.

faster (Chakraborty et al., 1997; Mali et al., 2017), whereas in the northern Bay of Bengal, the species grows at a rate of 0.3 year $^{-1}$ (Rajkumar et al., 2003). It is likely that differences occur in growth rates and longevity among Saurida spp. with different geographical distributions (Yoneda et al., 2002). Monsoon upwelling resulting in constant replenishment of nutrients affect the plankton bloom giving better environment for high trophic productivity along southeastern Arabian sea (Ghosh et al., 2014) which may be the one of the reasons for increased growth rate of $S$. undosquamis in the region. This information on the growth rate of 0.41 year $^{-1}$ obtained for southeastern Arabian Sea stock of $S$. undosquamis is lower than that reported from other parts of Arabian Sea (Chakraborty et al., 1997; Mali et al., 2017). Similar range of $\mathrm{K}$ value estimates using length-based methods were also reported from other tropical seas including South China Sea (Wang et al., 2012), Gulf of Suez (Amin et al., 2007) eastern Mediterranean Sea (Gokce et al., 2007) and from Gulf of Thailand (Boonanich, 1991). Even though in most estimates of $\mathrm{K}$ values using hard parts of the species are much lower than that obtained using length-based methods, Tureli and Erdem (1997) reported a higher K value of 0.59 for $S$. undosquamis from eastern Mediterranean using otolith-based method.

Beverton and Holt (1957) pointed out that natural mortality coefficient of a fish is directly related to the growth coefficient $(k)$ and inversely related to the asymptotic length $\left(L_{\infty}\right)$ and the life span. Similar observations were made in the case of $S$. undosquamis which had a higher growth coefficient and higher mortality rates compared to that of the stocks from northern Bay of Bengal. The mortality rate of $S$. undosquamis obtained in the present study confirms that reported earlier from northern Arabian Sea (Kalharo et al., 2014) and differs from those reported earlier from northeastern Arabian Sea and Gulf of Suez (Chakraborty et al., 1997; Amin et al., 2007; Mali et al., 2017).

The growth performance index reported for S. undosquamis from other tropical regions varied from 2.65 to 5.29 (Kadharsha et al., 2014), and the value of 2.96 obtained in the present study lies well within this range. Mahmoud et al. (2014) reported a growth performance index of 2.61 from Mediterranean coast of Egypt. However, the values reported from Bay of Bengal by Rajkumar et al. (2003) and by Kadharsha et al. (2014) were 3.61 and 4.9, respectively, which are higher estimates compared to that reported in the present study. 


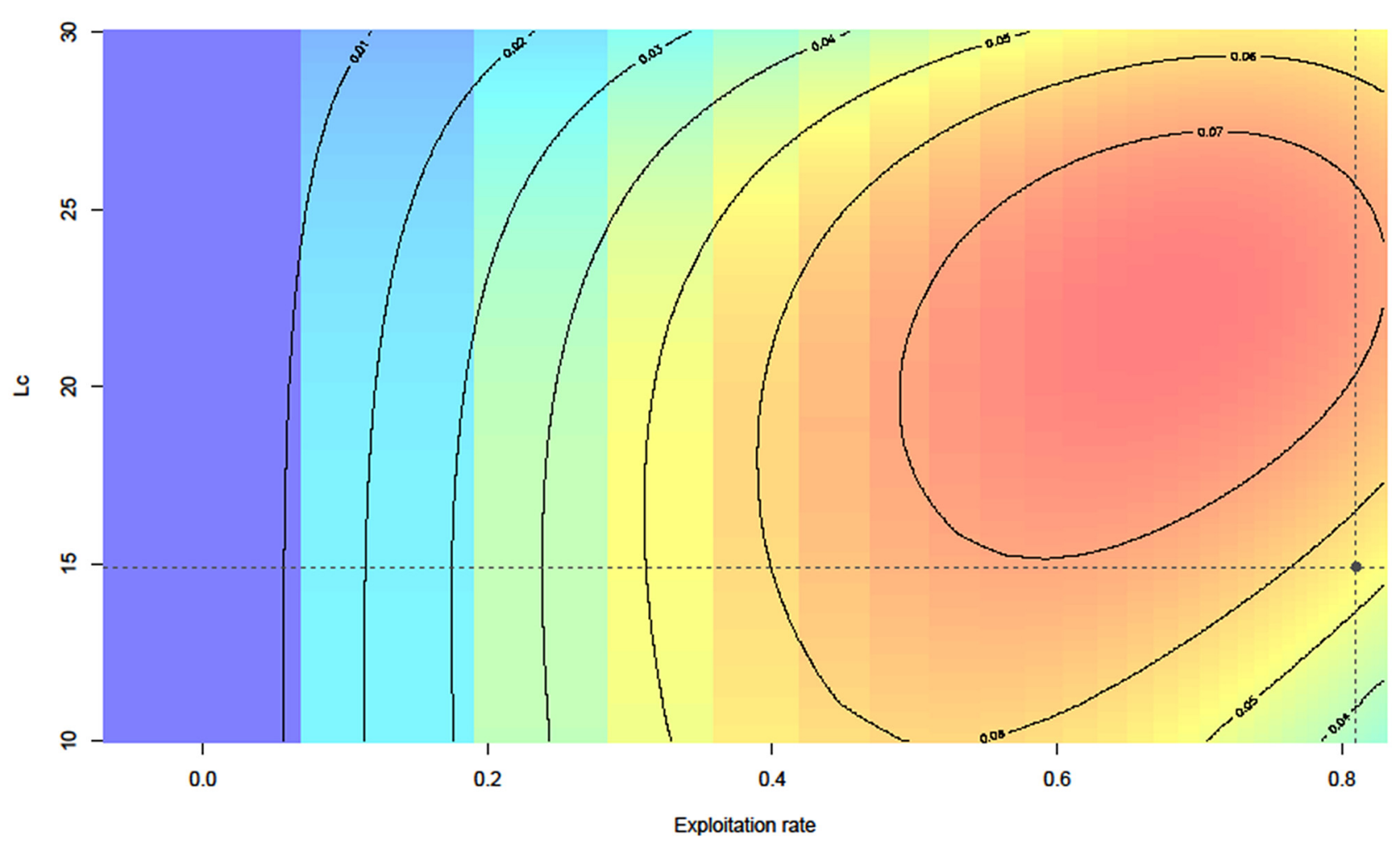

Fig. 7. Impact of different exploitation rates and $L_{\mathrm{c}}$ values on the yield per recruit of $S$. undosquamis. The x-axis displays the exploitation rate (F/ Z) of the fully-exploited length class(es).

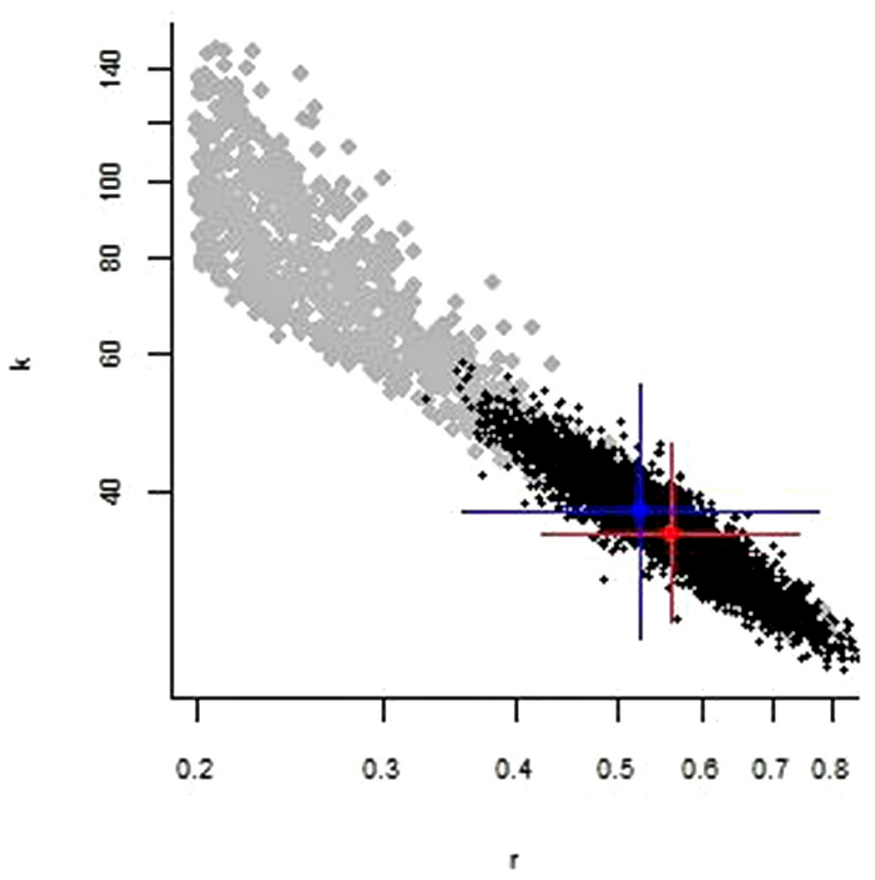

Fig. 8. Results of the CMSY/BSM analysis of $S$. undosquamis catch data from southeastern Arabian Sea for the period 1985-2016. The most probable $r-k$ pair and its approximate $95 \%$ confidence limits are shown in dark (BSM) and grey (CMSY) points.

\subsection{Exploitation and stock dynamics}

The exploitation rate obtained in the present study was much higher than that of 0.62 reported from northeastern Arabian Sea by Mali et al. (2017), 0.56 by Chakraborty et al. (1997) and 0.56 from Bay of Bengal by Rajkumar et al. (2003). The Exploitation rate of S.undosquamis in southeastern Arabian Sea was 0.82, which indicates that the fishery is either fully exploited or overexploited. Therefore, there is a need for appropriate management interventions to curtail the fishing pressure to ensure sustainability of the resource in the region.

Maximum sustainable yield (MSY) estimated using the length-based Thompson and Bell model is $5738 \mathrm{t}$, which is corresponding to the fishing effort of 0.6 from the current effort. Hence to achieve the maximum sustainable yield the effort should be reduced by $40 \%$ from the current fishing effort expended for harvesting the resource to sustain the stocks of $S$. undosquamis in the region. Any increase in fishing effort could result in overfishing of the stock in the region and the other resources which are harvested by the same gear. Since the exploitation ratio for $S$. undosquamis is higher than $\mathrm{E}_{0.5}$ and the value of MSY is lower than the annual average catch, the stock is under high fishing pressure than sustainable level in the region.

\subsection{CMSY/BSM analysis}

The estimation of fishery reference points using CMSY analysis heavily depends upon the catch and $r$ values. 
Table 1. Fisheries reference points based on Bayesian Schaefer model (BSM) analysis for the management of S. undsquamis stock in southeastern Arabian Sea.

\begin{tabular}{lll}
\hline Parameter & Value & Confidence limits \\
\hline$r$ & 0.561 & $95 \% \mathrm{CL}=0.425-0.742$ \\
$k$ & $35300 \mathrm{t}$ & $95 \% \mathrm{CL}=27100-45900 \mathrm{t}$ \\
Relative biomass in last year & $0.353 \mathrm{k}$ & $2.5^{\text {th }}$ perc $=0.24 ; 97.5^{\text {th }}=0.50$ \\
Exploitation $(\mathrm{F} /(r / 2)$ in last year & 1.78 & - \\
$\mathrm{F}_{\text {msy }}$ & 0.281 & $95 \% \mathrm{CL}=0.212-0.371$ \\
$\mathrm{MSY}$ & $4950 \mathrm{t}$ & $95 \% \mathrm{CL}=4510-5440 \mathrm{t}$ \\
$\mathrm{B}_{\text {msy }}$ & $17600 \mathrm{t}$ & $95 \% \mathrm{CL}=13600-23000 \mathrm{t}$ \\
Biomass in last year & $12400 \mathrm{t}$ & $2.5^{\text {th }}$ perc $=8470 \mathrm{t} ; 97.5$ perc $=17700 \mathrm{t}$ \\
$\mathrm{B} / \mathrm{B}_{\text {msy }}$ in last year & 0.705 & $2.5^{\text {th }}$ perc $=0.48 ; 97.5 \mathrm{perc}=1.0$ \\
Fishing mortality in last year & 0.5 & $2.5^{\text {th }}$ perc $=0.352 ; 97.5$ perc $=0.735$ \\
$\mathrm{~F} / \mathrm{F}_{\text {msy }}$ & 1.78 & $2.5^{\text {th }}$ perc $=1.26 ; 97.5$ perc $=2.62$ \\
\hline
\end{tabular}

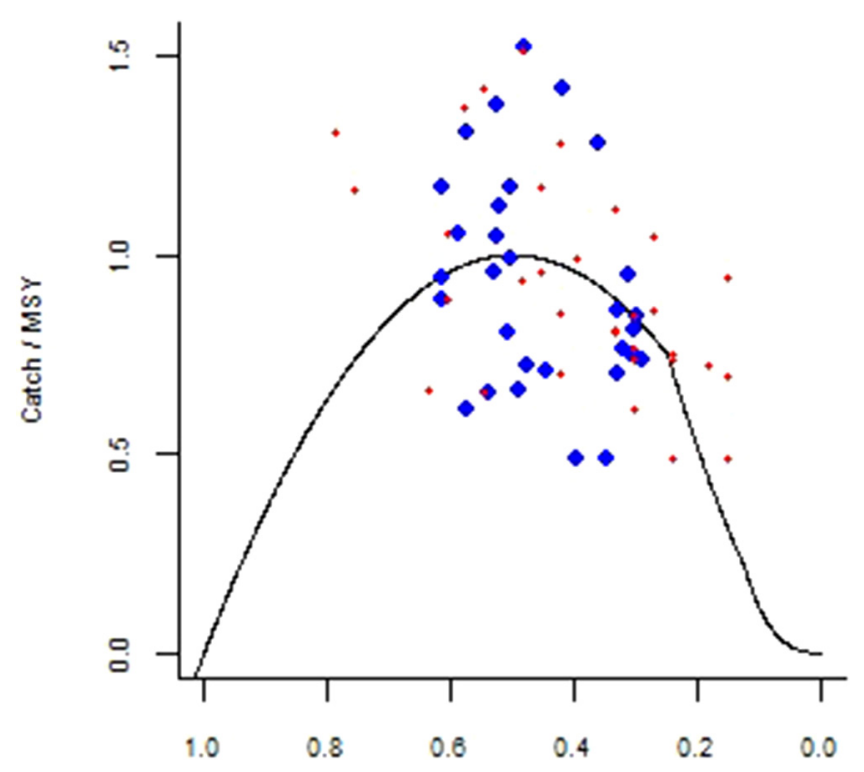

Relative biomass $\mathrm{B} / \mathrm{k}$

Fig. 9. Schaefer equilibrium curve of S. undosquamis catch/MSY relative to $\mathrm{B} / k$. Points not falling on the equilibrium curve indicates overfishing and shrinking of biomass, if above the curve, and sustainable exploitation and growing of stock, if below the curve.

Uncertainties in these two values will substantially weaken the results and it is suggested to estimate the $r$ value for the stock at the regional level based on the available biological information on the species (Palomares and Froese, 2017). The resilience categorisation from FishBase (Froese et al., 2000; Froese and Pauly, 2018) gave prior ranges of $r$ that led to reasonable CMSY and BSM fits for $S$. undosquamis. In the present analysis, CPUE is used as proxy for biomass. Froese et al. (2017) noted that when CPUE instead of biomass was available for analysis, the results showed that BSM and CMSY estimates were not significantly different in $89 \%$ of the stocks. Nevertheless, the data on biomass, even if it is available for very short time period, may be given due importance as an input parameter to the analysis. In the

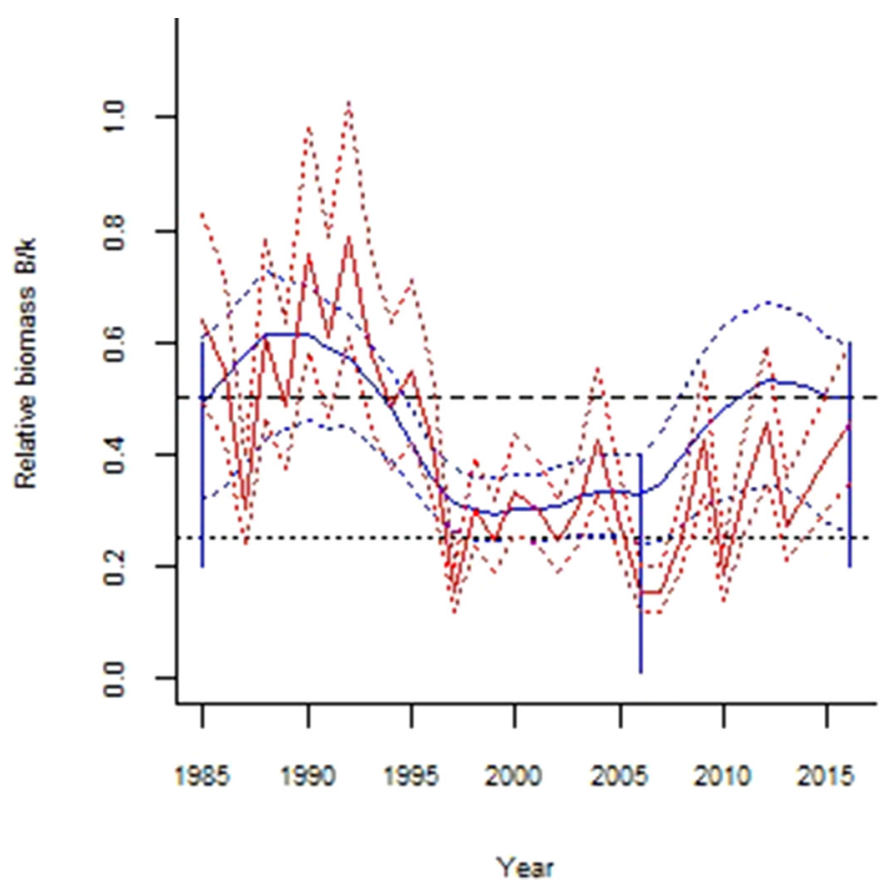

Fig. 10. CMSY predictions of relative biomass $B / k$ (bold curve) with $2.5^{\text {th }}$ and $95^{\text {th }}$ percentiles (thin curves) compared to observed biomass (dashed curve) scaled by the respective BSM estimate for $k$, for $S$. undosquamis stock in southeastern Arabian Sea.

fishery of $S$. undosquamis in the study area, the catch is contributed by many types of crafts and gears with greater part of the catch is by mechanised trawlers. In cases the species is harvested by multiple gears, Palomares and Froese (2017) suggest the use of CPUE from the most dominant gear type, i.e., that which catches more than $50 \%$ of the landings. Hence, the catch rates of mechanised multiday trawlers are considered for the present analysis.

The results of CMSY/BSM analysis using 25 years of catch data in the present study are in agreement with the results of stock assessment made using micro analytical models with five years length frequency and catch data with minor differences in MSY estimates. Both the analyses indicate that the stock of $S$. undosquamis in the region is either fully or over exploited 


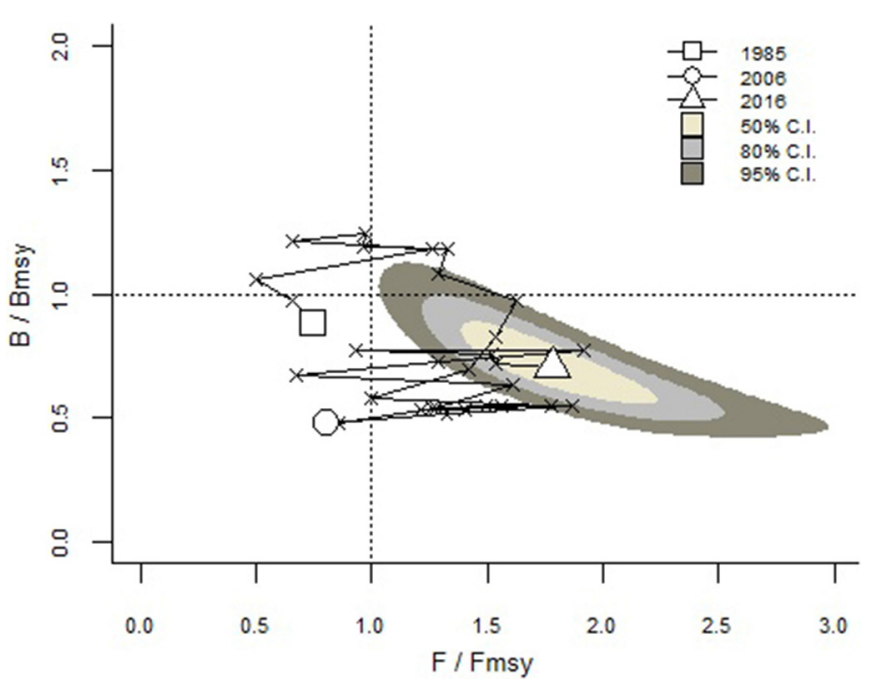

Fig. 11. Results of the BSM analyses relevant for management of $S$. undosquamis stock from the southeastern Arabain Sea. Figure shows the development of biomass and exploitation relative to $B_{\text {msy }}$ (horizontal dashed line) and $\mathrm{F}_{\mathrm{msy}}$ (vertical dashed line), respectively.

state. CMSY analysis points out an exploitation of 30\% below $\mathrm{B}_{\mathrm{msy}}$ level. However, Rosenberg et al. (2018) pointed out that stocks above $80 \%$ of $B_{\text {msy }}$ are conventionally considered "fully exploited", and stocks staying at this level for many years, forego substantial yield. In order to achieve a stock recovery with better future yields of $S$. undosquamis from southeastern Arabian Sea, the management advice from CMSY analysis is to reduce the catches from the current level until both CMSY and BSM predict biomass above $\mathrm{B}_{\mathrm{msy}}$ for two to three years in a row and then increase catches to the lower confidence limit of MSY. At that point, the lower $95 \%$ confidence limit of MSY is suggested as guidance for allowed catches (Froese et al., 2017).

The southwest coast of India is a classic example of upwelling driven fisheries, where the contribution of low trophic level fishes in the landings were high for most of the years, indicating the dominance of fish groups in low trophic categories. However, the contribution of other top predators, which were high during 1985-2000, sharply declined thereafter (Vivekanandan et al., 2005). They also report that the region remains as a distinct entity with the lowest mean trophic value (3.14), compared to the other three regions of seas around the coast of India, indicating fishing down to food web. Shifts from high-trophic-level predators to low-trophiclevel invertebrates and plankton-feeders in the fishery were reported globally (Pauly and Palomares, 2005). Trends in decline of mean trophic level (MTL) in catches due to human impacts, i.e., when predators collapse ("fishing down marine food webs") and when low-trophic-level fisheries expand ("fishing through marine food webs") were also reported (Pauly et al., 1998). Catch MTL is considered as a measure of changes in ecosystem MTL and biodiversity (Pauly and Watson, 2005). The exploitation of top predators like $S$. undosquamis along southeastern Arabian Sea need to be maintained at sustainable level to prevent ecosystem changes along the region. As this resource is harvested by trawls which targets and harvests a multispecies assemblage, a multispecies stock management approach should also be addressed prior to implement any controlling measures for the sustainable exploitation of this species.

\section{Conclusion}

The length at first capture estimated for $S$. undosquamis in the fishery in southeastern Arabian Sea is $14.9 \mathrm{~cm}$ which is much lower than the estimated size at first maturity. Moreover, the average annual mean length observed in the fishery is lower than the estimated optimum length for exploitation. This implies that the juveniles are target of fishery. The high vulnerability of juvenile individuals by mechanised trawling and the indiscriminate harvest of juveniles by this major fishing gear would affect the future yield of this species. The results indicate that reducing the present level of fishing effort by $40 \%$ would lead to a harvest of the species at a sustainable level. The predictions of stock size and exploitation status of $S$. undosquamis using length-based Thompson and Bell model confirm the predictions of CMSY/BSM Analysis. This indicates that the CMSY/BSM method designed specifically for the use in data poor environment can be effectively applied for the assessment of tropical Indian stocks wherever data for micro analytical models are lacking.

Acknowledgements. We thank the Director, ICAR-Central Marine Fisheries Research Institute, for providing necessary support and facilities. Thanks are due to Dr. Rainer Froese and his colleagues for providing appropriate training on the use of CMSY/BSM analysis for the assessment of Indian fish stocks.

\section{References}

Amin AM, El-Halfawy MM, Ramadan AM. 2007. Management and reproduction of male brushtooth lizardfish Saurida undosquamis (Richardson) from Gulf of Suez. Egypt J Aquat Biol Fish 11: 149162.

Bal DV, Rao KV. Marine fisheries, Tata McGraw Hill Publishing Co. LTD, New Delhi, 1984.

Beverton RJH, Holt SJ. On the dynamics of exploited fish populations, Fisheries Investigations, FAO Fisheries Technical Paper, 38 version, 19, Ministry of Agriculture and Fisheries, London, United Kingdom, 1957, 533 p.

Boonanich T. 1991. Population dynamics of Saurida elongata (Synodontidae) and $S$. undosquamis (Synodontidae) in the southern Gulf of Thailand. Fishbyte 9: 23-27.

Chakraborty SK, Desmukh VD, Zaffar Khan M, Vidyasagar K, Raje SG. 1997. Estimates of growth, mortality, recruitment pattern and MSY of important fishery resources from Maharashtra coast. $J$ Indian Fish Assoc 24: 1-39.

Cicek E, Avsar D. 2011. Growth, mortality and spatial distribution of brushtooth lizardfish, Saurida undosquamis (Richardson, 1848), inhabiting the Karatas coasts (Iskenderun Bay, northeastern Mediterranean). Acta Zool Bulg 63: 97-103.

Desai BN, Bhargava RMS. Biologic production and fishery potential of the Exclusive Economic Zone of India, in: K. Sherman, E. Okemwa, M. Nitiba (Eds.), Large marine ecosystems of the Indian Ocean: Assessment, sustainability and management, Blackwell Sciences, Cambridge, U.S., 1998, pp. 327-333.

El Ganainy AA. Biological studies on lizard fishes, Saurida undosquamis (Pisces: Synodontidae) from the Gulf of Suez, M. 
Sc. thesis, Faculty of Science, Ain Shams University, Cairo, Egypt, 1992.

FAO. Trends in oceanic captures and clustering of large marine ecosystems - Two studies based on the FAO capture database, FAO Fish Tech Pap, Food and Agriculture Organisation of United Nations, Rome, 2003, 435 p.

Froese R, Demirel N, Coro G, Kleisner KM, Winker H. 2017. Estimating fisheries reference points from catch and resilience. Fish Fish 18: 506-526.

Froese R, Pauly D. 2018. FishBase. World wide web electronic publication, Available from www.fishbase.org, version (06/2018) in June/July 2018.

Froese R, Palomares MLD, Pauly D. Estimation of life-history key facts, in: R. Froese, D. Pauly (Eds.), FishBase 2000: Concepts, design and data sources, ICLARM, Philippines, 2000, pp. 167-175.

Gayanilo FC Jr, Sparre P, Pauly D. FAO-ICLARM stock assessment tools (FiSAT) user's manual, FAO Comp Info Ser (Fisheries) 8, Food and Agriculture Organisation of United Nations, Rome, 1996, $126 \mathrm{p}$.

Ghosh S, Rao H, Rohit P, Rammohan K, Maheswarudu G. 2014. Reproductive biology, trophodynamics and stock structure of ribbonfish Trichiurus lepturus from northern Arabian Sea and northern Bay of Bengal. Indian J Geo-Mar Sci 43(5): 755-771.

Gokce G, Sangun L, Ozbilgin H, Bilecenoglu M. 2007. Growth and mortality of the brushtooth lizardfish (Saurida undosquamis) in Iskenderun Bay (eastern Mediterranean Sea) using length frequency analysis. J App Ichth 23(6): 697-699.

Gulland JA. 1979. Report of the FAO/UNDP workshop onthe fishery resources of the Western Indian Ocean-South Equator, FAO, Rome, 10FC/DEV/79/, 45, pp. 1-37.

Ingles J, Pauly D. 1984. An atlas of the growth, mortality and recruitment of Philippine fishes, ICLARM/ Tech Rep 13, ICLARM, Manila, $127 \mathrm{p}$.

Kadharsha K, Mohanchander P, Lyla PS, Khan AS. 2014. Age and growth of brushtooth lizardfish Saurida undosquamis (Richardson, 1848) occurring in Parangipettai, southeast coast of India. Indian J Geo-Mar Sci 43(9): 1799-1803.

Kalharo MA, Liu Q, Waryani B, Panhwar SK, Memon KH. 2014. Growth and mortality of brushtooth lizardfish, Saurida undosquamis, from Pakistani waters. Pak J Zool 46(1): 139-151.

Mahmoud HH, El Haweet AAK, Dimech M. 2014. Stock assessment of the alien species Brushtooth lizard fish, Saurida undosquamis (Richardson, 1848) in the Egyptian Mediterranean coast. Egypt J Aquat Res 40: 443-450.

Mali KS, Farejiya MK, Kumar VM, Rao RK, Bhargava AK. 2017. Population characteristics of greater lizardfish, Saurida tumbil (Bloch 1795) and brushtooth lizardfish, Saurida undosquamis (Richardson 1848) from the north western Indian EEZ. Int J Fauna Biol Stud 4(2): 124-130.

Manasirli M, Avsar D, Yeldan H. 2011. Population dynamical parameters of brushtooth lizard fish [Saurida undosquamis (Richardson, 1848)] from the northeastern Mediterranean Coast of Turkey. Ege J Fish Aquat Sci 28: 111-115.

Metar SY, Chakraborty SK, Jaiswar AK, Deepa S, Sajina AM. 2011. Studies on growth and stock assessment of Saurida undosquamis (Richardson, 1848) from Mumbai coast, India. Indian J Geo-Mar Sci 40: 59-61.

Najmudeen TM, Sathianandan TV, Zacharia PU. 2014. Fleet optimization of trawl fishery along southwest coast of India using surplus production model. J Mar Biol Assoc India 56(2): 74-80.
Nansimole S, Sruthi S, Gayathri Devi TV, Lekshmi S, Balasubramaniam NK, Teresa R. 2014. Studies on morphometry, feeding biology and sex ratio of Saurida undosquamis (Richardson, 1848) (Fam: Synodontidae) from Neendakara area, Kolllam, southwest coast of India. Indian J Sci Res 5(2): 51-58.

Palomares MLD, Froese R. Training on the use of CMSY for the assessment of fish stocks in data-poor environments. Workshop report submitted to the GIZ by Quantitative Aquatics, Inc. Q-quatics Technical Report No. 2, Bay Laguna, Philippines, 2017, $58 \mathrm{p}$.

Pauly D. 1979. Theory and management of tropical multispecies stocks. A review with emphasis on the south-east Asian demersal fisheries, ICLARM Stud Rev 1, ICLARM, Manila, 35 p.

Pauly D. A selection of simple methods for the assessment of tropical fish stocks, FAO Fish. Circ. Issued also in French. Supersided by FAO Fish. Tech. Pap. 729(234), Food and Agriculture Organisation of United Nations, Rome, 1980, $54 \mathrm{p}$.

Pauly D. 1983a. Length converted catch curves. A powerful tool for fisheries research in tropics (Part-1). ICLARM Fishbyte 1(2): 9-13.

Pauly D. Some simple methods for the assessment of tropical fish stocks, FAO Fisheries Technical Paper No.243, Food and Agriculture Organisation of United Nations, Rome, 1983b, 52 p.

Pauly D, Munro JI. 1984. Once more on the comparison of growth in fish and invertebrates. Fishbyte 2: 21-23.

Pauly D, Palomares M-L. 2005. Fishing down marine food web: It is far more pervasive than we thought. Bull Mar Sci 76: 197-211.

Pauly D, Watson R. 2005. Background and interpretation of the "Marine Trophic Index" as a measure of biodiversity. Phil Trans $R$ Soc B 360: 415-423.

Pauly D, Christensen V, Dalsgaard J, Froese R, Torres FJ. 1998. Fishing down marine food webs. Science 279: 860-863.

Prasanna Kumar S, Muraleedharan PM, Prasad TG, Gauns M, Ramaiah N, de Souza SN, Sardesai S, Madhupratap M. 2002. Why is the Bay of Bengal less productive during summer monsoon compared to the Arabian Sea? J Geophys Res 29: 88/1-88/4.

Rajkumar U, Sivakami S, Rao KN, Kingsly HJ. 2003. Lizardfish fishery, biology and population dynamics of Saurida undosquamis (Richardson) off Visakhapatnam. Indian J Fish 50(2): 149-156.

Rosenberg AA, Kleisner KM, Afflerbach J, Anderson SC, DickeyCollas M, Cooper AB, Fogarty MJ, Fulton EA, Gutiérrez NL, Hyde KJW, Jardim E, Jensen OP, Kristiansen T, Longo C, MinteVera CV, Minto C, Mosqueira I, Osio GC, Ovando D, Selig ER, Thorson JT, Walsh JC, Ye Y. 2018. Applying a new ensemble approach to estimating stock status of marine fisheries around the world. Conserv Lett 11(1): 1-9.

Sathianandan TV, Mohamed KS. Minimum legal size and its estimation, in: T.V. Sathianandan, K.G. Mini, S. Kuriakose (Eds.), Training manual on fish stock assessment and management, Central Marine Fisheries Research Institute, Kochi, 2014, pp. $118-124$.

Sivakami S. 1999. Fishery of lizardfishes off Cochin with a note on the biology of $S$. undosquamis (Richardson). The Fourth Indian Fishery Forum Proceeding, Kochi, 25-28 November 1996, pp. 245-248.

Sparre P. Computer programming for fish stock assessment. Lengthbased fish stock assessment (LFSA) for Apple computers, FAO Fish Tech Pap 101 (Suppl 2), 1987, 217 p.

Srinath M, Kuriakose S, Mini KG. 2005. Methodology for the estimation of marine fish landings in India. CMFRI Special Publication 86: 57.

Tureli C, Erdem U. 1997. The growth performance of red mullet (Mullus barbatus) and brushtooth lizardfish (Saurida undosquamis) from the 
coastal region of Adana province (Iskenderun Bay, Turkey). Turk $J$ Zool 21: 329-334.

Vivekanandan E. Stock assessment of tropical marine fishes, Indian Council of Agricultural Research, New Delhi, 2005, 115 p.

Vivekanandan E, Srinath M, Pillai VN, Immanuel S, Kurup KN. 2003. Marine fisheries along the southwest coast of India, in: G. Silvestre, L. Garces, I. Stobutzki, C. Luna, M. Ahmad, R.A. Valmonte-Santos, L. Lachica-Aliño, P. Munro, V. Christensen, D. Pauly (Eds.), Assessment, management and future directions for coastal fisheries in Asian Countries, World Fish Center Conference Proceedings, vol. 67, pp. 757-792.
Vivekanandan E, Srinath M, Kuriakose S. 2005. Fishing the marine food web along the Indian coast. Fish Res 72: 241-252.

Vivekanandan E, Gomathy S, Thirumilu P, Meiyappan MM, Balakumar SK. 2009. Trophic level of fishes occurring along the Indian coast. J Mar Biol Assoc India 51(1): 44-51.

Wang X, Qiu Y, Du F, Lin Z, Sun D. 2012. Population parameters and dynamic pool models of commercial fishes in the Beibu Gulf, northern South China Sea. Chin J Oceanol Limnol 30: 105-117. Yoneda M, Sakai T, Tokimura M, Horikawa H, Matsuyama M. 2002. Age and growth of the Lizardfish Saurida sp. in the East China Sea using otolith ring marks. Fish Res 55: 231-238.

Cite this article as: Najmudeen TM, Seetha PK, Zacharia PU. 2019. Stock dynamics of the brushtooth lizardfish Saurida undosquamis (Richardson, 1848) from a tropical multispecies fishery in the southeastern Arabian Sea. Aquat. Living Resour. 32: 9 